\title{
Response patterns in finger and central body skin temperatures under mild whole body cooling in an elderly and in a young male - a pre-study
}

Kalev Kuklane ${ }^{1 *}$, Leif Vanggaard ${ }^{2}$, Juhani Smolander ${ }^{1}$, Amitava Halder ${ }^{1}$, Karin Lundgren ${ }^{1}$, Chuansi Gao ${ }^{1}$, Jari Viik ${ }^{3}$, Jarmo Alametsä ${ }^{3}$

From 15th International Conference on Environmental Ergonomics (ICEE XV)

Portsmouth, UK. 28 June - 3 July 2015

\section{Introduction}

The arteriovenous anastomoses (AVAs) in distal body parts (especially hands and feet) and the peripheral veins draining them constitute the "AVA organ" that may provide around one third of the total skin surface area for heat exchange [1]. The temperatures over AVA-regulated skin sites are seldom taken into account and therefore actual heat loss may be underestimated, especially in studies employing mild whole-body cooling. The aim of this test was to study the response pattern of finger skin temperature (rich in AVAs) with non-AVA sites during transient whole-body cooling in an elderly and a young man.

\section{Methods}

Two subjects, old (78 years, weight $73 \mathrm{~kg}$, height $1.74 \mathrm{~m}$ ) and young (31 years, weight $70 \mathrm{~kg}$, height $171 \mathrm{~cm}$ ) volunteered. Rectal temperature (every $10 \mathrm{~s}$ ), skin temperature at 8 body sites and fingertips (every $10 \mathrm{~s}$ ), pulse (every $15 \mathrm{~s})$, cold discomfort/thermal sensation (10 min), IR-imaging (10 min), ballistocardiographic measurements with pressure-sensitive EMFi film sensor strips on the neck near carotid artery and on the right ankle, and a larger EMFi sensor on the seat beneath the measured person $[2,3]$ were recorded. Instrumentation (20-25 minutes) was carried out in a chamber at about $29^{\circ} \mathrm{C}$. The subjects were dressed in shorts and seated on chair with arms supported at the heart level, and right upper arm wearing blood pressure band. Ambient temperature

\footnotetext{
* Correspondence: kalev.kuklane@design.lth.se

'The Thermal Environment Laboratory, Division of Ergonomics and Aerosol Technology, Department of Design Sciences, Faculty of Engineering, Lund University, Lund, Sweden

Full list of author information is available at the end of the article
}

was set to $29{ }^{\circ} \mathrm{C}$ for 25 minutes and then gradually lowered at a mean rate of $0.13{ }^{\circ} \mathrm{C} \cdot \mathrm{min}^{-1}$ for the next 100 minutes stabilizing at $17{ }^{\circ} \mathrm{C}$. Mean (SD) air flow of $0.45(0.14) \mathrm{m} . \mathrm{s}^{-1}$ was directed into the back. After the cooling stabilized, bicycle ergometer exercise sessions $(50 \mathrm{~W})$ were added to observe the effect of exercise.

\section{Results and discussion}

Classical area-weighted mean skin temperature in the old and in the young person did not show differences. Rectal temperature and body heat content in the old person reduced at a quicker rate than in the young one. The old subject reported less discomfort and cold sensation as compared to the young. The temperature in extremities (hands, feet $=$ AVAs areas) dropped quicker and lower in the young subject than in the old. One major ballistocardiographic finding was that the systolic and diastolic amplitudes increased strongly, especially, with the older person reflecting the increased workload of the heart due to coldness. This was seen also in dramatically increased blood pressure values (diastolic $68->101$ and systolic $125->176 \mathrm{mmHg}$ ). Skin rewarming with the older person seemed to be more gradual as seen in cold limbs in thermal images.

\section{Conclusion}

The observations of this limited study indicate clear agerelated differences in the peripheral circulatory response to a mild cold challenge. The peripheral circulatory response may be associated with the normal aging process. If the present result holds true with a larger, and with a significant number of older people, then these findings might open up avenues to develop 'smart clothes' 
applications for the elderly population to compensate ambient temperature changes.

\section{Authors' details}

${ }^{1}$ The Thermal Environment Laboratory, Division of Ergonomics and Aerosol Technology, Department of Design Sciences, Faculty of Engineering, Lund University, Lund, Sweden. Danish Arctic Institute, Copenhagen, Denmark.

${ }^{3}$ Tampere University of Technology, BioMediTech, Tampere, Finland.

Published: 14 September 2015

\section{References}

1. Taylor NAS, Machado-Moreira CA, van den Heuvel AMJ, Caldwell JN: Hands and feet: physiological insulators, radiators and evaporators. European Journal of Applied Physiology 2014, 114(10):2037-2060.

2. Alametsä J, Smolander J, Vanggaard L, Halder A, Lundgren K, Gao C, Viik J, Kuklane K: Age-related circulatory responses to whole body cooling: observations by ballistocardiographic EMFi sensors. In Proceedings of Ambience14\&10i3m, Scientific Conference for Smart and Functional Textiles, Well-Being, Thermal Comfort in Clothing, Design, Thermal Manikins and Modelling, 7-9 September 2014. Tampere University of Technology, Tampere, Finland;Varheenmaa $M$.

3. Alametsä J, Kuklane K, Smolander J, Vanggaard L, Halder A, Lundgren K, Gao C, Viik J: Age-related circulatory responses to whole body cooling: observations by heart rate variability. Finnish Journal of eHealth and eWelfare 2015, 7(2-3):57-64.

\section{doi:10.1186/2046-7648-4-S1-A32}

Cite this article as: Kuklane et al:: Response patterns in finger and central body skin temperatures under mild whole body cooling in an elderly and in a young male - a pre-study. Extreme Physiology \& Medicine 2015 4(Suppl 1):A32.

\section{Submit your next manuscript to BioMed Central and take full advantage of:}

- Convenient online submission

- Thorough peer review

- No space constraints or color figure charges

- Immediate publication on acceptance

- Inclusion in PubMed, CAS, Scopus and Google Scholar

- Research which is freely available for redistribution

Submit your manuscript at www.biomedcentral.com/submit 